\title{
Second Language Acquisition in a study abroad context: Findings and research directions
}

\section{Adquisición de la segunda lengua en una experiencia de inmersión en el extranjero: resultados y enfoques de investigación}

\begin{abstract}
Alex Pinar ${ }^{1}$
Citation/ Para citar este artículo: Pinar, A. (2016). Second Language Acquisition in a study abroad context: Findings and research directions. Colomb. Appl. Linguist. J., 18(2), pp.p 83-94.

Received: 27-Oct-2015 / Accepted: 27-May-2016

DOI: http://dx.doi.org/10.14483/ calj.v18n2.9480

Abstract

The idea that living or studying in the target language country is essential in order to improve linguistic knowledge and understand its culture is widespread. Since the 1980s, a large amount of research has been conducted in order to describe empirically the linguistic benefits gained from the study abroad context. However, over the last decade researchers have expanded research fields and studied important aspects such as the development of intercultural competence and the influence of extra-linguistic factors during study abroad. The aim of this paper is to present a review and synthesis of the most relevant research projects undertaken during the last decade, highlight the different research lines that have been recently utilized, and comment on their findings. This paper also proposes new research directions that could allow us to understand the deeper complexities of the study abroad learning context.
\end{abstract}

Keywords: intercultural development, second language acquisition, study abroad, learning context, linguistic knowledge

\section{Resumen}

La idea de que es imprescindible estudiar en un país hablante de la lengua meta para poder llegar a dominarla está muy extendida. Desde los años ochenta se han realizado un gran número de investigaciones con el objetivo de describir de manera empírica la influencia real de las estancias en el extranjero en el conocimiento lingüístico. Pero en la última década se han abierto nuevas líneas de investigación que estudian otros aspectos relevantes como el desarrollo de la competencia intercultural y la influencia de factores extralingüísticos que pueden influir en el aprendizaje de lenguas en el extranjero. El objetivo de este artículo es presentar una revisión y síntesis de los trabajos más relevantes que se han llevado a cabo en la última década, mostrando las diferentes líneas de investigación que se han ido abriendo recientemente y discutiendo sus resultados. Se proponen también nuevas líneas de investigación que podrían ayudarnos a comprender mejor los distintos factores que influyen en el proceso de aprendizaje de lenguas en el extranjero.

Palabras clave: desarrollo de la competencia intercultural, adquisición de segundas lenguas, aprendizaje en el extranjero, contexto de aprendizaje, conocimiento lingüístico

1 Akita International University, Yuwa, Akita City. Japan. palex@aiu.ac.jp 


\section{Introduction}

The idea that living or studying in the target language country is essential to improve linguistic knowledge and understand its culture is widespread. One reason why study abroad is considered the best context for language learning is the belief that students will be constantly exposed to the L2, and they will receive real input more intensely than in a regular language course in their own country. Moreover, it is assumed the learners will find more opportunities to use the L2 outside of the classroom and interact with native speakers, thereby putting into practice what they have learned and developing communication strategies in real-life communicative situations (Collentine E Freed, 2004).

Collentine (2009) has noted that since the 1980s, a large number of research projects have been conducted that analyze the effects of the learning context in the language learning process. The aim of researchers was to describe the linguistic benefits gained from the study abroad context in relation to the improvement of communicative or pragmatic competence in the target language. Over the last decade, many researchers have continued analyzing the influence of study abroad in the acquisition of linguistic knowledge, especially in fluency (Allen $\mathcal{E}$ Herron, 2003; Llanes \& Muñoz, 2012; Segalowitz $\varepsilon$ Freed, 2004), in the knowledge of grammar and vocabulary (Collentine, 2004; Dewey, 2008; Isabelli $\varepsilon$ Nishida, 2005), in the development of written skills (Freed, So, \& Lazar, 2003; Sasaki, 2009), or in learning strategies (Adams, 2006). However, other researchers have expanded research fields and studied other important aspects, such as the development of intercultural competence (Berg, 2009; Engle E Engle, 2004; Jackson, 2009; Pinar, 2012), the influence of extra-linguistic factors such as the duration of the stay (Dwyer, 2004), culture shock (Lafford, 2004), living conditions such as the influence of living with host families (SchmidtRinehart \& Knight, 2004; Knight \& SchmidtRinehart, 2010), and the creation of social networks and interaction with native speakers (Kinginger, 2008; Magnan $\varepsilon$ Back, 2007), all of which can positively or negatively influence the relationship of the individual to the language and culture of the target language when studying abroad.
The aim of this paper is to present a synthesis of the most relevant research undertaken during the last decade, show the different research lines that have been recently utilized, and comment on their findings. The paper also proposes new research directions that could allow us to understand the complexity of the study abroad learning context.

\section{Second Language Acquisition in a Study Abroad Context}

The study abroad research body conducted in the last decade can be classified into four groups: (1) effects of study abroad on linguistic knowledge; (2) individual differences in the study abroad context; (3) development of intercultural sensitivity during study abroad; and (4) extra-linguistic factors that affect the learning process abroad, which will be discussed in turn.

Effects of study abroad on linguistic knowledge. As we noted above, in recent years, research has been carried out in an attempt to empirically describe the benefits in linguistic knowledge that study abroad provides. Most of those studies analyzed the effects of study abroad on oral proficiency, although some studies analyzed the impact of study abroad on writing skills, and grammatical and lexical knowledge.

Effects on oral proficiency and grammatical knowledge. The majority of studies that examine the effects of study abroad on oral proficiency have agreed on the idea that studying abroad helps to improve fluency and pronunciation. Allen and Herron (2003), for instance, found in their study conducted among twenty-five American students of French, those who studied in France improved their fluency after spending a summer studying abroad and showed more confidence and ability to perform oral tasks. Freed, So, and Lazar's (2003) findings were similar in a comparative study conducted among thirty American students of French who studied a semester in their own country or abroad. The results showed that students who studied abroad improved their ability at oral expression, especially in aspects of fluency, the speed of speech, grammatical correctness, pronunciation, and richness of vocabulary used. 
Segalowitz et al. (2004) also studied how students improved fluency, vocabulary, grammatical knowledge and pronunciation of forty-six American students of Spanish, twenty-six of whom studied in Spain and twenty in the United States. They found that the students who studied abroad improved oral expression skills (more fluency and use of a greater variety of vocabulary) compared to those who studied in their home country. In contrast to the study of Freed, So, and Lazar (2003), however, the students who studied in their home country showed a better mastery of grammar.

Segalowitz and Freed (2004) studied the relationships between psychological and contextual factors and their impact on the development of oral expression. In their research, they analyzed oral production skills and cognitive abilities of forty students out of which eighteen studied Spanish for a semester at a university in the United States and twenty-two in Spain. The results of this research highlighted that the students of the study abroad program showed significant progress in speaking/ oral fluency, although this improvement could not be explained by contact and exposure to the language outside of the classroom. According to the analysis of the data obtained, the improvement was attributed to each student's own learning abilities or the number of hours of class during study abroad (which was greater than in their home country). The study concluded that the cause of the limited influence of the context could be the shortness of the study abroad-one semesterwhich did not allow students to develop sufficient social relationships. Even communication with host families could be banal and repetitive, and consisted only of basic communicative exchanges, or in some cases, students simply did not take advantage of the opportunities to use the L2 outside of the classroom.

Freed, Segalowitz, and Dewey (2004) included the context of domestic immersion programs in their research about the influence of the learning context in the second language acquisition processes. The results of this study, carried out among twenty-eight American students of French (eight studied in France and twenty in the United States, eight in regular courses and twelve in immersion programs), showed that the students who studied in the regular courses in their own country in regular classes showed no significant improvement. Those who studied in immersion programs significantly improved their fluency. At the same time, the students who studied abroad showed less important improvement than those who participated in the immersion program, even though students from both groups attended nearly the same number of class hours. The investigation concluded that immersion students spoke and wrote in French for more hours per week than the students in regular courses and that the students abroad used more English than French outside the classroom during their stay. The analysis of the interviews showed that the time spent using the L2 outside the classroom and not the context determined the progress in fluency.

In regards to pronunciation, Díaz-Campos (2006) compared the advances of forty-six American students of low intermediate level Spanish learners for a semester (out of whom twenty studied in the United States and twenty-six in Spain). Quantitative phonological analysis showed that students who studied in a study abroad program had an overall improvement in pronunciation, except in the production of approximant intervocalic sounds, especially in conversations. Unlike the study of Segalowitz and Freed (2004), this research concluded that improvements in the pronunciation of students abroad were possible because they had more contact with native speakers, thus, their oral competence and pronunciation improved through informal conversations.

Regarding the development of grammatical knowledge, several comparative studies between different learning contexts have shown conflicting results. Collentine (2004) carried out research on the development of lexical and morphosyntactic knowledge and its production among two groups of American students of Spanish. One group spent a semester studying in the United States for two hours per week (twenty students) and the other group studied in Spain between three and five hours a day (twenty-six students). Collentine analyzed the use of grammatical categories and frequency of adjectives, adverbs, conjunctions, prepositions, and verbs used. Despite differences in the hours of class received, results showed that the students abroad did not 
gain a significant increase in grammatical skills. On the contrary, the students who studied in their own country demonstrated further development of knowledge in lexical and grammatical aspects, although the students who studied abroad showed greater discursive and narrative skills (wider variety of use of structures and tenses), and could produce more semantically elaborate discourse. The research concluded that this discursive and narrative ability was due to daily contact with the L2, which allowed the students abroad to explain their experiences and daily actions to native friends or host families. In other words, the regular contact meant that they learned to produce narrative speeches, which represented actual progress or improvement in the use of certain grammatical elements during the production of those speeches.

In contrast to the above, however, Isabelli (2004) and Isabelli and Nishida's (2005) comparative studies showed that studying in a natural context allowed students to develop more grammatical competence than in a domestic context. In the research conducted among thirty-one students of Spanish of intermediate level who studied in Spain, Isabelli (2004) studied the acquisition of the null subject (omission of the grammatical subject). Data analysis found that students who studied abroad had significantly improved their knowledge and use of grammar.

Similar results appeared in another research conducted by Isabelli and Nishida (2005) who studied the influence of studying abroad on the acquisition and mastery of the subjunctive mood of Spanish. The results illustrated those students who studied abroad significantly improved from the fourth semester (before which the advances were almost nonexistent), especially with the use of temporal adverbial subordinate structures. On the other hand, there was no significant progress on the results of the interviews carried out among students at home after the fifth and sixth semesters. Also, differences in subjunctive use between the at-home and abroad students were significantly different. The students abroad showed progress and a much broader mastery since 59\% of the interviews with this group showed production of structures with the subjunctive while $20 \%$ of students at home produced such structures.
Effects on lexical knowledge and writing abilities. Research on the impact of study abroad on vocabulary acquisition agrees that this context encourages learning and expansion of vocabulary. Dewey (2008), for instance, compared the lexical acquisition of American students of Japanese in three learning contexts (abroad, at home, and immersion at home). The aim of this research was to determine if there was any difference in the vocabulary acquisition among these contexts. This study involved fifty-six students, out of whom twenty were in Japan, fourteen were participating in an immersion program in the United States, and twenty-two were studying in regular programs at various universities in the United States. The results were similar to the study of Segalowitz and Dewey (2004), which revealed that students in immersion programs attained a higher level of lexical learning, superior to the students at home and abroad since they had greater exposure to the language by being forced to speak Japanese with their peers throughout the program. The students abroad showed a more significant breakthrough in lexical knowledge than the students at home, which was due to the increased exposure and use of the target language outside of the classroom. Even though the research also found that students abroad who improved less were the ones that used more English outside of the classroom, read more internet pages in English, or communicated often with friends and family from their home country. The analysis of these results also illustrated that the time spent using the target language outside of the classroom was more decisive for progress in the acquisition of vocabulary than the context.

Concerning the influence of the context on the improvement of writing skills, results of research vary substantially depending on the nationality of the students and the language studied. Freed, So, and Lazar (2003), for example, analyzed the influence of learning context in the development of the writing skills of thirty North American students who studied a semester in their own country (fifteen) or France (fifteen). Data analysis found that students who learned in a domestic context wrote better than those who were overseas, so it could not be concluded that writing became more fluid as a result of having spent a semester in the 
L2-speaking country. On other hand, Sasaki (2009) conducted a study among twenty-two Japanese students of English, (seventeen studying abroad and five studying in Japan). The results illustrated that the "scores" obtained by the students abroad were higher than the students at home. At the same time, students abroad improved their written skills and displayed more motivation to perform writing tasks in comparison to the students at home.

Individual differences in the study abroad context. In the last decade, much research has been carried out with the aim to analyze the role of individual differences during study abroad such as learning strategies (Adams, 2006; Lafford, 2004; Paige, Cohen, \& Shively, 2004), students' beliefs (Amuzie \& Winke, 2009; Tanaka \& Ellis, 2003), and age (Llanes \& Muñoz, 2012).

In regard to the learning strategies applied studying abroad, Lafford (2004) points out that the learning context has a significant influence on the use of communication strategies such as self-correction, the self-test of accuracy, and restructuring of the message. The research consisted of forty-six students of Spanish during a semester (twenty in the own country and twenty-six in Spain) and revealed that students who studied abroad showed significantly less dependence on the use of communicative strategies than those who studied in their own country. That was attributed to the fact that students abroad had been more exposed to communicative situations daily, which helped them to improve their communicative competence and interact with native speakers without the need to resort to communicative strategies to fill the gaps between their inter-language and the L2.

On the other hand, Paige, Cohen, and Shively (2004) studied the learning strategies used by eighty-six American students of French (nineteen) and Spanish (sixty-seven) that studied a semester abroad in Spain, France, and other Spanish and French speaking countries. The analysis of the data obtained before and after their stay found that when studying abroad, students increased the amount and frequency of learning strategies (in particular, those related to listening comprehension and oral expression). In addition, Adams (2006) also studied the use of learning strategies abroad with one hundred and thirty-two American students of Spanish, French, German and Portuguese who went to different countries to study in programs lasting between two to four months. The analysis of data obtained through questionnaires performed before and after their stay demonstrated, to the contrary, that there had not been a significant development of these strategies, most likely due to the short length of the programs.

In relation to the students' beliefs abroad, Tanaka and Ellis (2003) studied the changes that occur in their beliefs about the language learning process and their linguistic competence. The results of their research, carried out with one hundred and sixty-six Japanese students of English who studied at an American university for one semester (fifteen weeks), showed an increase in linguistic knowledge and communicative competence and reflected that significant changes had occurred in the students' beliefs during study abroad, especially those relating to self-efficacy, capacity or ability to learn, and the way of learning. Amuzie and Winke (2009) also support Tanaka and Ellis's findings that changes occur in students' beliefs during study abroad. The results of their research, carried out with seventy students from different countries who studied in the United States for periods ranging from several weeks to two years, showed that, regardless of the length of the stay, there were changes in beliefs relating to learning. Most students developed strong beliefs about the importance of autonomy in learning, while, at the same time, they changed their views regarding the importance and role of the teacher.

In contrast, to study the relationship between age and the learning context, Llanes and Muñoz (2012) conducted a comparative study with seventythree children (of whom thirty-nine studied abroad between two to three months, and thirty-four in their own country) and sixty-six adults (forty-six studied abroad between two to three months, and twenty in their own country). The results displayed that, generally, study abroad promotes fluency in both children and adults. The study also explained that children who studied abroad made greater progress than adults who studied abroad, and when compared to adults and children (in this order) who studied in 
their own country. On the other hand, adults who had studied abroad showed greater improvement in oral production of complex vocabulary than adults who had studied in their own country, and those children who studied abroad or at home. The analysis illustrated that studying abroad promotes fluency development more in children than in adults; however, it did show that study abroad improves lexical knowledge more in adults than in children.

\section{Intercultural Sensitivity Development During Study Abroad}

Research about intercultural sensitivity development in the study abroad context finds that a stay abroad encourages intercultural development. Engle and Engle (2004) examined two hundred fiftyseven American students of French, who studied a semester or a year in France. Their research found that there is a relationship between the length of stay abroad and understanding of the culture. Results showed that intercultural sensitivity and cultural adaptation developed more significantly during the second half of the one-year stay.

In research carried out among twenty-eight American students of Spanish who studied in Mexico (eighteen in summer courses for seven weeks and ten during one semester), Medina-Lopez-Portillo (2004), also found a relationship between the length of stay and the development of intercultural sensitivity. Students who studied longer (for sixteen weeks) developed more intercultural competence than those who studied for seven weeks. The same work also highlighted that previous linguistic knowledge may have allowed greater participation in extracurricular activities, and therefore, such students were better prepared to become involved with the local culture and develop cultural sensitivity. Berg (2009) also highlighted the importance of the length of the stay in the development of intercultural sensitivity but argued that female students developed it more significantly than male students.

Jackson (2009) also found, in his research conducted among thirteen students from Hong Kong who studied in England for a semester, that even a short-length stay allowed almost all students to develop their intercultural sensitivity and their intercultural competence, and also to have a better understanding and acceptance of cultural differences. For this researcher, pre-departure preparation and adequate support during the stay were more important for the development of cultural sensitivity than the length of the stay. On the other hand, Pinar (2012) pointed out that intercultural sensitivity development is conditional on the students' age. He remarked that children that go abroad do not have enough intellectual maturity to learn and understand some cultural characteristics (beliefs, values, symbols, customs, social conventions, and so on). Moreover, at early ages it is difficult to develop intercultural skills and identify cultural differences that can affect communication and create misunderstandings.

\section{Extra-Linguistic Factors that Affect the Learning Process Abroad}

Some extra- linguistic factors may positively or negatively affect the experience of study abroad. Those factors are related to the length of stay, the living conditions, and the quantity and quality of interaction with native speakers through the creation of social networks. All such elements can influence the students' learning experience decisively.

Length of stay and living conditions. The duration of the stay abroad may vary depending on the program of studies carried out. Summer language courses, for example, tend to last from one to several weeks, while studies in universities tend to take place during a semester or a full academic year. Several studies have been conducted to determine the real influence of the length of stay. Research findings show that advances occur in linguistic knowledge and communicative competence even in programs of several weeks of duration, especially in oral expression. For example, Segalowitz et al. (2004), in a comparative study of North American students who studied Spanish in the United States and in Spain between three and five weeks, found that students who were in Spain improved fluency and could use a greater variety of vocabulary. Allen and Herron (2003) also showed that students of French who studied for a summer in France significantly improved their fluency. Similar results were obtained in the research of Llanes and Muñoz 
(2009), which pointed out that Spanish students of English developed their capacity for listening comprehension and fluency after a stay of two or three weeks in English speaking countries. On the other hand, in relation to intercultural sensitivity, studies such as those of Engle and Engle (2004), Medina-López-Portillo (2004), and Berg (2009) showed that intercultural sensitivity and cultural adaptation developed much more significantly when the stay was longer.

Dwyer (2004) noted that the length of stay could influence several aspects of the experience. According to this author, studying abroad for a whole year instead of one semester or several weeks allowed students to develop more confidence in their own linguistic knowledge, which could improve academic success. At the same time, longterm students had more options to interact with native speakers and create social networks, which meant more opportunities to practice the language, improve communicative competence, and develop tolerant attitudes toward other cultures.

The most common living conditions during study abroad are staying with host families, living in student residences, or in shared bedrooms. Each type of those accommodations can positively or negatively influence both the learning process and the perception of the host culture that students have. Living with host families is one of the most frequent accommodation options during study abroad and it is considered to be more beneficial for language learning because it provides social and cultural interaction. Allen, Dristas, and Mills (2006), in a study conducted among students of different languages who lived with host families, shared bedrooms, or residences of students, found that those who lived with host families showed much greater progress in acquiring the linguistic knowledge and the level of identification with the target culture than students who stayed in dormitories or student residences.

Although it is considered that this choice of accommodation is most suitable because it provides more opportunities for interaction with native speakers, it has been found that the effects of staying with host families are not always positive. The experience living with host families may be positive or negative depending on the type of relationship that is established with the members of those families, since it may affect the amount of time that is shared and the dynamics and quality of the interactions between family members and the student (Lafford \& Collentine, 2006). One of the determinant aspects in the relationship between the student and host family, and therefore in the learning process, is the way in which both perceive their respective roles. The families that host female students and assume a role of a mother or teacher to them often contribute to their learning, by talking with them and teaching them different linguistic or cultural aspects. On the other hand, families who consider themselves as owners who rent out a room or as parents who have to control the students, tend to relegate the students and make it difficult for them to be integrated into the family, or also tend to impose obligations on them by assigning tasks and responsibilities to be carried out to be able to be part of the family (Churchill \& DuFon, 2006).

Research studies such as those by Knight and Schimdt-Rienhart (2002), Schmidt-Rinehart and Knight (2004), and McMeekin (2006) show that when host families play a cooperative role, this facilitates high quality interaction that allows students to practice the language, be corrected and receive new input at the same time, which very positively affects the development of linguistic and cultural knowledge. On the other hand, Isabelli-García (2006) shows in his research work an example of the adverse effect of staying with a family where the student is considered a tenant who rents a room. In that case, contact and interaction between them was almost non-existent, preventing the practice of language and the development of communicative competence and intercultural sensitivity.

In relation to the dynamics of the interaction, several studies show some disadvantages of this type of accommodation. Dufon's (2006) work shows that when conversations with the family occur infrequently, for a short period of time such as during meals, students could not practice frequently. Jackson (2006) also describes how sometimes problems of adaptation may occur, usually related to sharing meals, the kind of food and the host family customs. Magnan and Lafford (2012) point 
out that other factors, such as the lack of patience to communicate with students who have a low language level, lack of time to talk to them because of differences in schedules, the incompatibility of personalities or situations of stressful coexistence, also negatively affect the learning process.

In relation to the dormitories, Yang and Kim (2011) found that the fact of sharing a room with another student who is a native speaker does not mean more opportunities to interact and to improve the communicative competence. These researchers showed the case of a Korean student who studied in the United States and who stayed in a dormitory at the university, thinking that the fact of living with a native speaker would bring him more opportunities to practice the language, that his mistakes would be corrected by the other, and that would help him to improve his fluency. In that case, the native student showed no interest in conversations and did not seem interested in the development of the linguistic competence of his Korean partner. The situation made him end up doubting the usefulness of sharing a bedroom with a native speaker and resulted in him spending free time with other students of his nationality. As such, the context of learning abroad did not favor learning, so the results of his TOEFL test did not improve significantly.

Social networks and interaction with native speakers. Social networks that are created during the stay abroad have a critical influence on linguistic knowledge since those social networks allow a greater amount of interaction with native speakers and practicing the target language more frequently, which helps to improve communicative competence. Campbell (2011) points out that some factors such as attending classes with native students, living with host families, and participation in extracurricular or cultural activities may facilitate the creation of social networks.

Magnan and Lafford (2012) identify three types of social networks: the ones that the student creates with native speakers, the ones that are built with fellow students of the same nationality, and the ones that remain, virtually, with friends and family of the country of origin. Students who normally have an open and receptive attitude are usually able to create social networks with native speakers and have greater advances in communicative competence and a stronger cultural knowledge than those who prefer to spend free time interacting with speakers of their own language or maintaining constant contact with the country of origin through the internet and virtual social networks.

Kinginger (2008) and Isabelli-García (2006) show that the students who can create social networks with native speakers have more opportunities to practice and improve the language. Isabelli-García's research work, for instance, describes some examples, such as the case of students who have difficulty in establishing social networks with native speakers and explaining how frustrations make the students give up and adopt an ethnocentric attitude, finally preferring to spend all time with other students from the same country. The researcher also describes the case of another student who was involved in community life by participating in volunteer programs, which allowed him to make local friends and finally experience a process of acculturation, and which had a positive impact on the development of his linguistic knowledge and his communicative competence.

Segalowitz and Freed (2004) reported the relationships between the creation of social networks and the length of stay. They pointed out that a semester of study abroad was too short and did not allow social relations to develop sufficiently. Lafford (2006) also showed that students did not always see the necessity to interact with native speakers and that they preferred to spend their leisure time doing other kind of activities that did not require using the L2, so interaction with native speakers was almost non-existent. In those cases, hardly any effect on linguistic knowledge or on communicative competence was observed.

\section{Discussion}

We can observe from the studies presented above-particularly those concerning the development of language skills-the positive effects of study abroad on fluency and pronunciation, regardless of the duration of the stay (e.g., DiazCampos 2006; Freed, So, E Lazar, 2003). On the 
other hand, concerning grammatical and lexical knowledge, studies showed different results. For instance, Collentine (2004) and Allen and Herron (2003) have pointed out that significant progress does not always occur after having studied a semester in an L2 speaking country, while, on the other hand, works of researchers such as Isabelli and Nishida (2005) or Isabelli (2004) have shown that notable advances are found after studying abroad, especially among those who have a more advanced level. Moreover, there have been divergent conclusions regarding the development of writing abilities. Freed, So, and Lazar (2003) have shown in their comparative study that students who remained in their own country wrote better than those who studied abroad, but Sasaki (2009), on the contrary, has noted that students who learned abroad wrote better than those who stayed in their country during the same period.

Research work that compared different contexts, such as the work by Freed, Segalowitz, and Dewey (2004), has equally shown different findings. Students who studied in programs of immersion in their own country improved their fluency and learnt more grammar and vocabulary than those who studied abroad or in regular courses in their own country. That can be explained by the fact that the context of immersion learning allowed students to perform communication tasks similar to those required while studying abroad, almost without any cultural or social obstacles and emotional barriers (Dewey, 2008). In relation to intercultural sensitivity, Engle and Engle (2004), Medina-Lopez-Portillo (2004), or Berg (2009) have shown that study abroad had a positive influence, even though the length of the stay was short.

Studies on the influence of extra-linguistic factors during study abroad have shown that similar phenomenon can affect the learning process differently. On the one hand, some studies related to the length of stay have shown that even in short stays it was possible to improve linguistic knowledge (Allen \& Herron, 2003; Llanes \& Muñoz, 2009; Segalowitz et al., 2004). On the other hand, studies such as those by Engle and Engle (2004), Medina-Lopez-Portillo (2004), and Berg (2009) have highlighted that long stays allowed, more significantly than the short ones, the development of intercultural sensitivity and may have led a complete cultural adaptation.

On the other hand, research on the living conditions has shown that living with host families often influences the learning process positively, although some researchers have observed that this option can also bring negative effects. Allen et al. (2006) found that students who lived with host families showed progress in linguistic knowledge and a level of identification with the target culture much higher than students who stayed in dormitories or student residences. Knight and Schimdt-Rienhart (2002), Schmidt-Rinehart and Knight (2004), and McMeekin (2006) have provided examples of the positive effects associated with staying with host families who assumed a cooperative role, but on the other hand, Isabelli-García (2006) and Jackson (2009) have shown how the interaction with the family can sometimes be troubled or almost nonexistent, thus preventing the practice of language and the development of communicative competence and intercultural sensitivity.

The real possibilities to interact with native speakers and create social networks that study abroad provides are one of the factors that has generated more controversy. Some researchers do not agree with the established ideas about the potential of exposure to the target language and the possibility of using it outside the classroom that study abroad provides. Researchers such as Lafford (2006) doubt that study abroad would provide more opportunities to use the language and interact with native speakers. Among other reasons, students did not always see the necessity to communicate with native speakers and, therefore, chose to spend free time doing other kinds of activities that did not require the use of the target language.

Coleman and Chafer (2010) have also questioned the idea that study abroad provides greater exposure to the L2 and more possibilities to interact with native speakers, since over the past decade access and development of the media have transformed the experience of living in another country. Cheap and easy access to communication platforms such as Skype have sprung up in recent 
years, the use of smart phones with internet access is widespread, and the use of social networks such as Facebook or Twitter and apps like WhatsApp, Line, or Telegram that allow immediate contact with friends and family has become popular. The accessibility of the new media allowing students to keep in touch with their own culture through the internet means that many students perceive striving to interact socially and participate actively in the local culture as unnecessary, which can hinder or even prevent a real process of acculturation that is necessary, according to the theory of Schumann, to assimilate the values and cultural behaviors of the speaker of the L2 community.

The research methods used and the validity of the results concerning the linguistic benefits are also subject to controversy. Researchers such as Coleman (2013) have criticized the validity of the results, the methodology and data used in studies comparing different learning contexts with the objective of determining linguistic progress. He has criticized that numerous studies attempted to empirically demonstrate linguistic gains without taking into account that each learning context is unique, and without considering sociolinguistic aspects, individual variables, or extra linguistic factors. For this reason, it is essential that the research of the acquisition of second languages abroad consider that learners are not a group of people who experience the same learning experience, but they are individuals with unique experiences. In this sense, Ushioda (2009) has highlighted the need to study the influence of the context in the development of linguistic knowledge, by taking into consideration, social or individual factors, which can affect each student differently.

\section{Conclusion}

As we have noted above, some of the current studies have highlighted the need to expand the scope of research and, rather than analyzing quantitative data on the gains in the linguistic knowledge, analyze more in depth aspects such as the social context in which the student studies, the individual differences (motivation, learning strategies, personality, etc.), and the extra-linguistic factors which may positively or negatively influence the learning process abroad.

It would also be important to study other relevant aspects such as how the nationality or mother tongue of the students may have an influence on the linguistic gains or in the success or failure in creating social networks, how the language level prior to departure to study abroad may facilitate or make difficult the learning process and the interaction with native speakers, or the attitude students abroad have outside of the classroom.

Moreover, the rise of social networks and new technologies also makes it necessary to carry out a study to describe who uses them among students studying abroad, whether they help or hinder the relationship with native speakers, or whether they create an environment to live virtually in their country of origin or, on the contrary, they do not prevent such acculturation processes. The findings could be useful for teachers and organizers to prepare and advise students for their stay abroad, so that the experience would become more fruitful and successful, both from the personal and the linguistic perspectives. We suggest qualitative research methods, such as life stories, to study the new research directions mentioned above. Narrative research may let us understand learning beliefs and experiences abroad from the students' perspective.

\section{References}

Adams, R. (2006). Language learning strategies in the study abroad context. In M. A. DuFonss $\&$ E. Churchill (Eds.), Language learners in study abroad contexts (pp. 259-292) Clevedon: Multilingual Matters.

Allen, H., \& Herron, C. (2003). A mixed methodology investigation of the linguistic and affective outcomes of summer study abroad. Foreign Language Annals, 36(3), 370-385.

Allen, H., Dristas, V., \& Mills, N. (2006). Cultural learning outcomes and summer study abroad. In M. Mantero (Ed.), Identity and second language learning: Culture, inquiry, and dialogic activity in educational contexts (pp. 189-215). Charlotte, NC: Information Age Publishing. 
Amuzie, G. L., E Winke, P. (2009). Changes in language learning beliefs as a result of study abroad. System, 37(3), 366-379.

Berg, M. V. (2009). Intervening in student learning abroad: A research-based inquiry. Intercultural Education, 20(sup1), 15-27.

Campbell, R. (2011). The impact of study abroad on Japanese language learners' social networks. New Voices, 5, 25-63.

Churchill, E., \& DuFon, M. A. (2006). Evolving threads in study abroad research. In M. A. DuFon $\&$ E. Churchill (Eds.), Language learners in study abroad contexts (pp. 1-27). Clevedon: Multilingual Matters.

Coleman, J., \& Chafer, T. (2010). Study abroad and the Internet: physical and virtual context in an era of expanding telecommunications. Frontiers: The Interdisciplinary Journal of Study Abroad, 19, 151167.

Coleman, J. A. (2013). Researching whole people and whole lives. In C. Kinginger (Ed.), Social and cultural aspects of language learning in study abroad (pp. 17-44). Amsterdam: John Benjamins.

Collentine, J. (2004). The effects of learning contexts on morphosyntactic and lexical development. Studies in Second Language Acquisition, 26(2), 227-248.

Collentine, J. (2009). Study abroad research: Findings, implications and future directions. In $M$. H. Long $\mathcal{E}$ C. J. Catherine (Eds.), The handbook of language teaching (pp 218-233). New York: Wiley.

Collentine, J., \& Freed, B. (2004). Learning context and its effects in second language acquisition. Studies in Second Language Acquisition, 26, 153-171.

Dewey, D. (2008). Japanese vocabulary acquisition by learners in three contexts. Frontiers: The Interdisciplinary Journal of Study Abroad, 15, 127148.

Díaz-Campos, M. (2006). The effect of style in second language phonology: An analysis of segmental acquisition in study abroad and regular-classroom students. In C. A. Klee \& T. L. Face (Eds.), Selected proceedings of the 7th conference on the acquisition of Spanish and Portuguese as first and second languages (pp. 26-39). Somerville, MA: Cascadilla Press.

DuFon, M. A. (2006). The socialization of taste during study abroad in indonesia. In M. A. DuFon \& E. Churchill (Eds.), Language learners in study abroad contexts. (pp. 91-119). Clevedon: Multilingual Matters.

Dwyer, M. (2004). More is better: The impact of study abroad program duration. Frontiers: The Interdisciplinary Journal of Study Abroad, 10, 151163.
Engle, L., \& Engle, J. (2004). Assessing language acquisition and intercultural sensitivity development in relation to study abroad program design. Frontiers: The Interdisciplinary Journal of Study Abroad, 10, 219-236.

Freed, B., So, F., E Lazar, N. (2003). Language learning abroad: How do gains in written fluency compare with gains in oral fluency in French as a second language? ADFL Bulletin, 34(3), 34-40.

Freed, B., Segalowitz, N., \& Dewey, D. (2004). Context of learning and second language fluency in French: Comparing regular classroom, study abroad, and intensive domestic immersion programs. Studies in Second Language Acquisition, 26(2), 275-301.

Isabelli, C. A. (2004). The acquisition of NSP properties in SLA: Some effects of positive evidence in a natural learning setting. Hispania, 87, 150-162.

Isabelli, C. A., E Nishida, C. (2005). Development of the Spanish subjunctive in a nine month study-abroad setting. In D. Eddington (Ed.), Selected proceedings of the 6th conference on the acquisition of Spanish and Portuguese as First and Second Languages (pp. 78-91). Somerville, MA: Cascadilla Press.

Isabelli-García, C. (2006). Study abroad social networks, motivation and attitudes: Implications for second language acquisition. In M. A. DuFon $\mathcal{E}$ E. Churchill (Eds.), Language learners in study abroad contexts (pp. 231-258). Clevedon: Multilingual Matters.

Jackson, J. (2006). Ethnographic pedagogy and evaluation in short-term study abroad. In M. Byram $\mathcal{E}$ A. Feng (Eds.), Living and study abroad: Research and practice (Vol. 12; pp. 134-156). Clevedon: Multilingual Matters.

Jackson, J. (2009). Intercultural learning on short-term sojourns. Intercultural Education, 20 (sup1), 59-71.

Kinginger, C. (2008). Language Learning in study abroad: Case studies of Americans in France. Modern Language Journal, 92, 1-124.

Knight, S. M., \& Schmidt-Rinehart, B. D. (2002). Enhancing the homestay: Study abroad from the host family's perspective. Foreign Language Annals, 35, 190-201.

Knight, S. M., E Schmidt-Rinehart, B. D. (2010). Exploring conditions to enhance student/host family interaction abroad. Foreign Language Annals, 43, 64-71.

Lafford, B. (2004). The effect of the context of learning (classroom vs. study abroad) on the use of communication strategies by learners of Spanish as a second language. Studies in Second Language Acquisition, 26(2), 201-226. 
Lafford, B. (2006). The effects of study abroadvs. classroom contexts on Spanish SLA: Old assumptions, new insights and future research directions. In C. A. Klee $\varepsilon$ T. L. Face (Eds.) Selected proceedings of the 7th conference on the acquisition of Spanish and Portuguese as first and second languages (pp. 1-25). Somerville, MA: Cascadilla Proceeding Project.

Lafford, B., \& Collentine, J. (2006). The effects of study abroad and classroom contexts on the acquisition of Spanish as a second language: From research to application. In B. Lafford \& R. Salaberry (Eds.), Spanish second language acquisition: From research findings to teaching applications (pp. 103126). Washington, DC: Georgetown University Press.

Llanes, À., E Muñoz, C. (2009). A short stay abroad: Does it make a difference? System 37(3), 353-365.

Llanes, À., E Muñoz, C. (2012), Age effects in a study abroad context: Children and adults studying abroad and at home. Language Learning, 63, 63-90.

McMeekin, A. (2006). Negotiation in a Japanese study abroad setting. In M. A. DuFon $\&$ E. Churchill (Eds.), Language learners in study abroad contexts (pp. 177-202). Clevedon: Multilingual Matters.

Magnan, S., \& Back, M. (2007). Social interaction and linguistic gain during study abroad. Foreign Language Annals, 40(1), 43-61.

Magnan, S., \& Lafford, B. (2012). Learning through immersion during study abroad. In S. Gass \& A. Mackey (Eds.). The Routledge handbook of second language acquisition (pp. 525-540). New York: Routledge.

Medina-Lopez-Portillo, A. (2004). Intercultural learning assessment: The link between program duration and the development of intercultural sensitivity. Frontiers: The Interdisciplinary Journal of Study Abroad, 10, 179-199.

Paige, R. M., Cohen, A. D., \& Shively, R. L. (2004). Assessing the impact of a strategies-based curriculum on language and culture learning abroad. Frontiers: The Interdisciplinary Journal of Study Abroad, 10, 253-276.
Pinar, A. (2012). La influencia de las estancias en el extranjero en el proceso de aprendizaje de segundas lenguas: Análisis de experiencias a través de relatos de vida lingüística. Marcoele: Revista de Didáctica de Español Lengua Extranjera, 15. Retrieved from http://marcoele.com/estancias-en-el-extranjero-vidalinguistica/

Sasaki, M. (2009). Changes in EFL students' writing over 3.5 years: A socio-cognitive account. In R. Manchón (Ed.), Learning, teaching and researching writing (pp. 49-76) Clevendon: Multilingual Matters.

Schmidt-Rinehart, B., \& Knight, S. (2004). The homestay component of study abroad: Three perspectives. Foreign Language Annals, 37(2), 254-262.

Segalowitz, N., \& Freed, B. F. (2004). Context, contact, and cognition in oral fluency acquisition: Learning Spanish in at home and study abroad contexts. Studies in Second Language Acquisition, 26, 173199.

Segalowitz, N., Freed, B., Collentine, J., Lafford, B., Lazar, N., Díaz-Campos, M. (2004). A comparison of Spanish second language acquisition in two different learning contexts: Study abroad and the domestic classroom. Frontiers: The Interdisciplinary Journal of Study Abroad, 10, 1-18.

Tanaka, K., E Ellis, R. (2003). Study-abroad, language proficiency, and learner beliefs about language learning. JALT Journal 25(1), 63-85.

Ushioda, E. (2009). A person-in-context relational view of emergent motivation, self and identity. In Z. Dörnyei $\mathcal{E}$ E. Ushioda (Eds.), Motivation, language identity and the L2 self (pp. 215-228). Bristol: Multilingual Matters.

Yang, J. S., E Kim, T. Y. (2011). Sociocultural analysis of second language learner beliefs: A qualitative case study of two study-abroad ESL learners. System, 39(3), 325-334. 